\title{
Criação em processo: das narrativas do desejo de Pedro Almodóvar
}

A ELABORAÇÃO E PRODUÇÃO DO DISCURSO, construído através da criação da obra de arte, é um gesto de descoberta, guiado por uma intuição amorfa, um conceito, uma premissa geral ou mesmo uma miragem que provoca o artista a sair em busca do conhecimento do que tem a dizer com a obra. Assim, um filme é sempre um mundo a ser descoberto.

O cineasta espanhol Pedro Almodóvar acredita que o tema esteja dentro dele e que é preciso percorrer várias etapas de trabalho para que ele o descubra, já que considera a escrita como uma grande aventura. Incialmente, o cineasta desconhece o que tem a dizer e somente o processo da escrita irá torná-lo consciente do discurso que, na maioria das vezes, ao final, é diferente daquilo que pretendia dizer ${ }^{2}$ :

O artista não inicia nenhuma obra com uma compreensão infalível de seus propósitos. Se o projeto fosse absolutamente explícito e claro ou se houvesse uma predeterminação, não haveria espaço para desenvolvimento, crescimento e vida, sendo assim, um processo puramente mecânico. Há sim uma sensação de aventura. ${ }^{3}$

Dessa maneira, não existe uma ideia muito fechada e pronta anterior à produção da obra, pois é através da ação do artista que a obra vai se revelando, as tendências poéticas vão aos poucos se definindo, em constante estado de transformação e construção. Esse processo possui um lento maturar, num "tempo que tem um clima próprio e que envolve o artista por inteiro" ${ }^{4}$, um tempo que não é guiado pelo relógio e que exige do artista um estado de adesão, ou seja, o artista vive a criação, rompendo as fronteiras do ambiente de trabalho, invadindo os espaços do seu cotidiano, podendo descobrir novas dimensões da obra em criação, pois a criação é um ato permanente. Nesse sentido, Salles afirma que:

O crescimento e as transformações que vão dando materialidade ao artefato que passa a existir, não ocorrem em segundos mágicos, mas ao longo de um percurso de maturação. O tempo do trabalho é o grande sintetizador do processo criador. A concretização das tendências se dá exatamente ao longo desse processo permanente de maturação ${ }^{5}$.

Assim, Pedro Almodóvar, narrando sobre as etapas do processo de criação de um filme, reflete sobre o estado de adesão, que Salles aponta como uma das características do movimento criador, podendo se apoderar até dos sonhos do artista, e como constata Almodóvar, capaz de impedi-lo de dormir:

\footnotetext{
${ }^{1}$ Mestranda em Comunicação e Semiótica pela Pontifícia Universidade Católica de São Paulo. Bolsista da CAPES. Contato: contatodanismith@gmail.com

${ }^{2}$ STRAUSS, F. Conversas com Almodóvar. Rio de Janeiro: Jorge Zahar Editora Ltda, 2008, p.77

${ }^{3}$ SALLES, C. Almeida. Gesto Inacabado. São Paulo: Intermeios, 2013, p. 47

${ }^{4}$ Ibidem, p. 40

${ }^{5}$ Ibidem.
} 


\begin{abstract}
Os primeiros esboços são muito enxutos; ali, o importante é que a intriga funcione, com sua lógica, e que me interesse. Para isso basta escrever uma espécie de relatório linear em que todos os elementos da intriga são expostos. Nesse primeiro desenvolvimento posso ver se o argumento me emociona e, como diz em espanhol, me quita el sueño. Isso quer dizer que a história que você escreveu se apodera de seus sonhos e o impede de dormir, porque você está tomado por ela. É exatamente isso que sinto quando escrevo um roteiro que me agrada. Se me sinto assim, escrevo uma segunda versão, na qual descubro os cenários, onde aparecem comentários literários sobre elementos de segundo plano. Quando escrevo, há sempre, antes do diálogo, anotações sobre os personagens, sobre o que sentem, suas motivações, a forma como falam. Sempre para evitar mal-entendidos. E também para que aqueles que trabalham no filme tenham o máximo de informações capazes de ajudá-los no que vão fazer. Isso não impede que depois se improvise, durante minhas filmagens se improvisa muito ${ }^{6}$.
\end{abstract}

Assim, ao sentir que a estória que inventa lhe tira o sono, Almodóvar passa ao processo de reescritura, fazendo muitas anotações para que o universo ficcional ali esboçado vá ganhando materialidade fílmica. Como ele diz, estas anotações também direcionam o trabalho da equipe durante a filmagem. Neste caso, o enredo do filme funciona como elemento gerador, sendo que este enredo pode ter sido iniciado a partir de outros estímulos, pois o artista é permeado durante o trajeto criativo pela sensibilidade, pensamentos, anseios e nesse caminho, ele pode encontrar novos estímulos, portanto, uma imagem, "uma inscrição no muro, imagens da infância, um grito, conceitos científicos, sonhos, um ritmo, experiências da vida cotidiana" ${ }^{7}$ podem agir como elementos estimulantes para a criação ou mesmo podem ser determinantes para o encontro de "soluções de obras em andamento" ${ }^{\prime 8}$.

Neste gesto permanente da criação, muitas vezes o artista parte de um estado inicial de insatisfação e, aos poucos, constrói um sistema, no qual desenvolve a relação e a conexão entre diferentes elementos narrativos, materiais, estéticos, com o outro e com a sua própria história, para então criar a sua autoria, a obra que será apresentada ao público, lembrando que essa obra não deve ser vista como um objeto símbolo da perfeição e esse olhar para a obra deve abranger também o seu processo de elaboração. Ela é o resultado de um processo marcado pela busca de uma profunda e particular verdade, em termos peirceanos, uma verdade artística, que o artista tenta materializar através da obra, mas ao mesmo tempo, é uma verdade que talvez o artista nunca consiga expressar integralmente. E a percepção de que essa possibilidade não foi alcançada, pode levar o artista a desejar começar um novo trabalho, construindo, dessa maneira, o conjunto da sua obra. Este aspecto é esclarecido por Salles:

Muitos artistas descrevem a criação como um percurso do caos ao cosmos. Um acúmulo de ideias, planos e possibilidades que vão sendo selecionados e combinados. As combinações são, por sua vez, testadas e assim opções são feitas e um objeto com organização própria vai surgindo. O objeto artístico é construído deste anseio por uma forma de organização. ${ }^{9}$

Portanto, durante o processo de criação, a verdade emerge da obra, uma verdade artística, ou seja, a verdade buscada pelo artista, mas que também é absolutamente mutável, podendo ser derrubada por uma nova verdade, que surge durante a criação. No entanto, "a verdade da arte tem um comprometimento diferente daquela da verdade científica: é uma ficção regida pelo projeto poético do artista. Trata-se de uma verdade

\footnotetext{
${ }^{6}$ STRAUSS, F. Op. Cit., 2008, p.29

${ }^{7}$ SAlLES, C. Almeida. Op. Cit., 2013, p. 61

${ }^{8}$ Ibidem.

${ }^{9}$ Ibidem, p. 41
} 
passível de verificação, segundo os princípios daquele que a constrói”10. Sendo assim, cada obra possui a sua própria verdade, já que cada obra possui o seu sistema, com leis e critérios que foram definidos e criados pela sensibilidade e a inteligência de um artista. E esse mundo poético e fictício em construção possui a sua própria força e energia, chegando a ocorrer etapas, durante a criação, em que o artista parece ser conduzido pela força da obra, sentindo que os personagens falam por si ou que as ações acontecem guiadas por essa energia da criação. Assim, "não se pode negar que a nova realidade em formação adquire energia e força ao ganhar organicidade" ${ }^{\text {" }}$. Portanto, todo o trabalho do artista é direcionado para a descoberta e a construção da poética de cada obra, plena de sua verdade, pois é dona de sua própria coerência interna, revelando a profunda relação entre forma e conteúdo, uma pesquisa que direciona as experimentações do artista, em busca da obra em criação.

Pedro Almodóvar afirma, em entrevista a Frederic Strauss, que escreve diferentes versões do roteiro, com múltiplas propostas de cenas, as quais são ensaiadas com os atores antes de filmar, como se fosse uma peça de teatro. Na sala de ensaio, ele testa diferentes possibilidades dramatúrgicas, adequando este material ao ator, ou seja, ele chega ao roteiro final após um processo de improvisação com os atores, sendo que, algumas cenas são definidas a partir dos seus corpos e possibilidades dramáticas, moldando a personagem ao ator, pois para ele, "nada pode igualar o que sai dos corpos, a força da expressão ao vivo". ${ }^{12}$

Com a estrutura do filme fechada, no set de filmagem, ele não faz mudanças no enredo, mas continua improvisando as situações com os atores, muitas vezes, utilizando propostas de cenas escritas, mas que não entraram no roteiro final. Para o cineasta é importante ter em mãos informações que os atores desconhecem para poder improvisar. Sendo assim, o roteiro que chega à filmagem não pode ser considerado como um texto final. Almodóvar revela que, durante a filmagem de "Ata-me", lançado em 1990, surgiu a necessidade de entendimento e de adaptação entre ele e a atriz Victoria Abril, pela sua forma de trabalhar:

Tivemos de fazer uma aprendizagem mútua, porque o método de trabalho dela não tinha nada a ver com o meu. Victoria quer sempre se sentir segura antes de filmar. Mesmo que eu prepare todas as minhas cenas com antecedência, há muitas coisas que só surgem quando começo a filmar, e ela não estava habituada a improvisar tanto, nem que um diretor lhe pedisse tantas coisas à última hora. Isso a perturbava, preocupava-a. Eu não queria que ela decorasse seus diálogos, para que estivesse completamente aberta, e ela só compreendeu essa forma de trabalhar - foi o que me disse - quando percebeu que não precisava inventar, porque eu inventaria tudo, e ela só precisava ser extremamente flexível para apanhar, em pleno vôo, todas as ideias que eu lhe lançava. Victoria estava também muito desconcertada com sua personagem, que exprime sentimentos à flor da pele. Era uma mulher pronta a explodir, a gritar, mas com um enorme pudor de manifestar os sentimentos e as emoções mais simples, como pessoa e como atriz. Isso lhe dava medo, não apenas porque era necessário que fosse convincente, mas porque exijo um envolvimento pessoal da atriz. Foi um percurso que fizemos juntos. ${ }^{13}$

Ao relatar sobre a sua relação de trabalho com a atriz protagonista do filme, Almodóvar revela como durante o processo de filmagem inúmeras possibilidades de criação surgiam, fazendo com que o resultado final fosse a expressão das escolhas artísticas, realizadas a cada momento. Assim, o movimento criativo "é a convivência de mundos possíveis. O artista vai levantando hipóteses e testando-as permanentemente. Como

\footnotetext{
${ }^{10}$ Ibidem, p. 136

${ }^{11}$ Ibidem, p. 135

${ }^{12}$ STRAUSS, F. Op. Cit., 2008, p.231

${ }^{13}$ Ibidem, p. 120
} 
consequência, há, em muitos momentos, diferentes possibilidades de obras habitando o mesmo teto. Convive-se com possíveis obras: criações em permanente processo.” 14

Essa perspectiva relativiza a noção de conclusão da obra de arte, pois o filme final, tal como é apresentado ao público, pode ser encarado como o resultado de um momento do processo de criação, corroborando a perspectiva de que não existe um começo, nem um fim no processo criativo, pois em uma obra habitam inúmeras outras.

Além do mais, esta maneira do cineasta conduzir o processo de construção de um sistema fílmico, ensaiando com os atores, testando diferentes possibilidades de cenas, para chegar à cena final filmada, nos revela que o fazer artístico é um processo onde existem etapas a serem cumpridas a fim de capturar camadas mais profundas de conteúdos significativos. Ou seja, uma obra de arte é fruto de investigação e de experimentação, que são guiadas pela lógica da incerteza, pois a sua prática criativa o provoca a ir tateando o universo da obra, o obrigando a fazer escolhas, em uma relação com a obra que envolve "seleções, apropriações e combinações, gerando transformações e traduções" ${ }^{\prime 15}$. São os gestos da criação que podem transformar tudo aquilo que o artista encontra em si e no mundo. Gestos incertos, muitas vezes feitos a partir da crise, da falta e da busca de respostas, que geram novas perguntas, de descobertas ou confrontos capazes, inclusive, de implodir a obra. Salles discorre sobre este aspecto do caminho da criação:

O percurso criador mostra-se como um itinerário não linear de tentativas de obras, sob o comando de um projeto de natureza estética e ética, também inserido na cadeia da continuidade e sempre inacabado. É a criação como movimento, em que reinam conflitos e apaziguamentos. Um jogo permanente de estabilidade e instabilidade, altamente tensivo. ${ }^{16}$

Essa tensão e esse jogo permanente de estabilidade e instabilidade percorrem o mundo em que o artista vive, determinado pelo tempo histórico, a cultura, a sociedade, e a sua visão de mundo penetra o universo da obra e vice versa. A seleção de técnicas e a linguagem estética da obra surgem a partir das afinidades subjetivas do artista com a obra de outros artistas, cujas obras lhe servem de referência, pois "a partir do que o artista quer e daquilo que ele rejeita, conhecemos um pouco mais do seu projeto" ${ }^{17}$ Portanto, a obra é também fruto das interações que o artista estabelece com a tradição.

Muitos críticos e criadores discutem a questão que não há criação sem tradição: uma obra não pode viver nos séculos futuros se não se nutriu dos séculos passados. Nenhum artista, de nenhuma arte, tem seu significado completo sozinho. Assim como o projeto individual de cada artista insere-se na tradição, é também, dependente do momento de uma obra no percurso da criação daquele artista específico: uma obra em relação a todas as outras já por ele feitas e aquelas por fazer. ${ }^{18}$

Estes aspectos são claramente encontrados nos filmes de Pedro Almodóvar. Estão muito presentes na relação do diretor com os filmes e textos que lhe afetaram a sensibilidade, já que a partir deste diálogo com a obra de outros autores, ele determina direcionamentos estéticos e de linguagem no seu trabalho. O cineasta afirma utilizar certos filmes como parte ativa de seus roteiros, integrando um trecho assistido à película que está

\footnotetext{
${ }^{14}$ SALles, C. Almeida. Op. Cit., 2013, p. 34

${ }^{15}$ Ibidem

${ }^{16}$ Ibidem, p. 35

${ }^{17}$ Ibidem, p. 48

${ }^{18}$ Ibidem, p. 49
} 
criando. Tais elementos passam a fazer parte da história em construção, convertendo o filme que assistiu em sua experiência, e transformando-a na experiência de suas personagens. ${ }^{19}$

Dessa maneira, a relação do diretor com a tradição é convertida em materialidade fílmica, em um diálogo entre aquilo que foi criado e aquilo que está criando e, algumas vezes, utilizando a sua própria produção como referência para este diálogo, através da elaboração de uma rede de operações lógicas e sensíveis, pois é através dessas operações que a criação artística acontece ${ }^{20}$. Essas operações ocorrem porque "o artista é um receptáculo de emoções" ${ }^{\prime 1}$, transitando através de diferentes referências e criando relações únicas entre elementos, por vezes, díspares, deixando-se ser conduzido pelo sensível, vivenciando o estado de poesia, que é irregular, fugidio, imprevisível, assimétrico, frágil, que o artista perde ou obtém por acidente, pois neste processo, "o estado de criação mantém a sensibilidade suspensa, à espera e à procura de emoções que, na medida que ativam sensivelmente o artista, são criadoras”. ${ }^{22}$

$\mathrm{O}$ artista dialoga com aquilo que lhe afeta o sensível, utilizando imagens e ideias que o provocam a criar conexões com o material que está manipulando. Almodóvar conta que após a morte de sua mãe, em 1999, ele viajou de férias para a ilha de Lanzarote e que as cores e a natureza desse lugar lhe provocaram grande impacto. No texto abaixo, o "Mateo" que ele cita, é a personagem do filme "Abraços Partidos", de 2009.

Assim como as cores do Caribe me pegaram na juventude, minha viagem à Lanzarote desenvolveu pela primeira vez meu fascínio pelo preto e pelos meios tons mais escuros de vermelho, verde, marrom e cinza. Como consagração do mistério da ilha, tirei a foto na praia de El Golfo. Como Mateo, também não tinha visto o casal se abraçando na parte de baixo da foto, descobri quando em uma loja de revelação em vinte e quatro horas, me deram a cópia impressa. A paisagem era impressionante, mas o que me impactou foi a descoberta do casal abraçado e sozinho, pequeno frente à imensidão da paisagem. Devido à deformação profissional (talvez pensando na foto do parque londrino de Blow Up, cuja ampliação revelou um cadáver escondido em alguns arbustos), imaginei que aquele abraço furtivo escondia um segredo e que eu tinha provas fotográficas. Queria descobrir tudo acerca do casal, ou ao menos alguns detalhes com os quais tecer uma ficção. Procurei o casal durante os dias que permaneci em Lanzarote, mas não o encontrei, imaginei a situação deles e escrevi várias opções fictícias que terminaram no abraço solitário, mas nenhuma delas me despertavam interesse. Voltei a Lanzarote e voltei a procurar na paisagem vulcânica uma ficção que incluísse o abraço da praia El Golfo, sem encontrar nada que me satisfizesse. O segredo do abraço resistia de ser revelado. Eu tinha a ilha como cenário. Tratei de introduzi-lo em todos os roteiros que escrevi desde então, mas não encontrei a história que lhe pertencia até 2007-2008, quando terminei o roteiro de Os Abraços Partidos. ${ }^{23}$

Essa imagem, capturada pela câmera e só percebida quando revelada a foto, provoca no diretor uma série de perguntas e inquietações, a tal ponto, que ele começa a escrever diversas possibilidades ficcionais para a imagem. Em sua descrição, podemos observar como a paisagem do local lhe provoca a descoberta de cores, e como a fotografia faz com que ele inicie um processo de investigação sobre os personagens retratados, como a

\footnotetext{
${ }^{19}$ STRAUSS, F. Op. Cit., 2008, p. 68

${ }^{20}$ SALLES, C. Almeida. Op. Cit., 2013, p. 59

${ }^{21}$ Ibidem, p. 61

${ }^{22}$ Ibidem.

${ }^{23}$ Tradução livre: Pedro Almodóvar in DunCAN, Paul, en colaboración con PEIRÓ, Bárbara. Los Archivos de Pedro Almodóvar.

Köln: Taschen, 2017, p.364
} 
imagem suscita o seu diálogo com a tradição, pois o remeteu ao filme Blow Up, de Michelangelo Antonioni, e como ele inicia um processo de criação a partir dessa visita e da imagem produzida ocasionalmente.

Sendo assim, percebemos que existe a ação do acaso, pois ao fotografar a paisagem que o impactara, Almodóvar fotografou duas "personagens" que passaram a provocar o seu imaginário, fazendo com que ele iniciasse uma investigação acerca da história contida por trás daquela imagem, que o levou a mergulhar num fluxo de busca e estabelecer relações complexas entre os elementos. No processo de criação, a ação do acaso possibilita que o artista insira novos elementos na obra ou descubra novos direcionamentos criativos. No entanto, a entrada do acaso na obra de arte é um movimento complexo. Salles considera que:

Discutir a intervenção do acaso no ato criador vai além dos limites da ingênua constatação da entrada, de forma inesperada, de um elemento externo ao processo. Por um lado, o artista, envolvido no clima da produção de uma obra, passa a acreditar que o mundo está voltado para sua necessidade naquele momento; assim, o olhar do artista transforma tudo para seu interesse, seja uma frase entrecortada, um artigo de jornal, uma cor ou um fragmento de um pensamento filosófico. ${ }^{24}$

A partir dessa perspectiva, percebemos, através do relato de Almodóvar, que a fotografia não foi um elemento que se incorporou à sua obra de uma maneira simples. Ele chegou a abandonar a história, acreditando que ela se reduzia a um cenário, que passou a incorporar aos seus filmes, até que conseguiu escrever o roteiro de "Abraços Partidos", filme lançado em 2009. Ou seja, foram 10 anos entre o encontro do cineasta com as cores de uma ilha e com uma fotografia, com a imagem de um casal abraçado na praia, até a exibição do filme ao público. O que só corrobora o fato de que a criação possui um lento maturar, e que foi preciso um estado de adesão e uma certa obsessão do cineasta, tentando, de diferentes maneiras, encontrar o enredo por trás de uma imagem, para que então ele conseguisse chegar ao filme final. Para o artista Piero Manzoni, são imagens que provocam o artista a sair em busca de novos sentidos ou de novas imagens:

A dificuldade está em libertar-se dos fatos estranhos, dos gestos inúteis: fatos e gestos que poluem a arte usual de nossos dias, e que por vezes são tão evidenciados que chegam ao ponto de se transformar em emblema de modos artísticos. $\mathrm{O}$ crivo que permite tal separação entre o autêntico e a escória, que nos leva a descobrir, em uma sequência incompreensível e irracional de imagens, um complexo de significados coerentes e ordenados, é o processo de auto análise. É através dele que nos reconectamos a nossas origens, eliminando todos os gestos inúteis. ${ }^{25}$

\footnotetext{
${ }^{24}$ SALLES, C. Almeida. Op. Cit., 2013, p. 42

${ }^{25}$ FERREIRA, Glória; COTRIM, Cecilia. Escritos de artistas: anos 60/70/ seleção e comentários. Rio de Janeiro: Jorge Zahar Ed., 2006, p. 35
} 


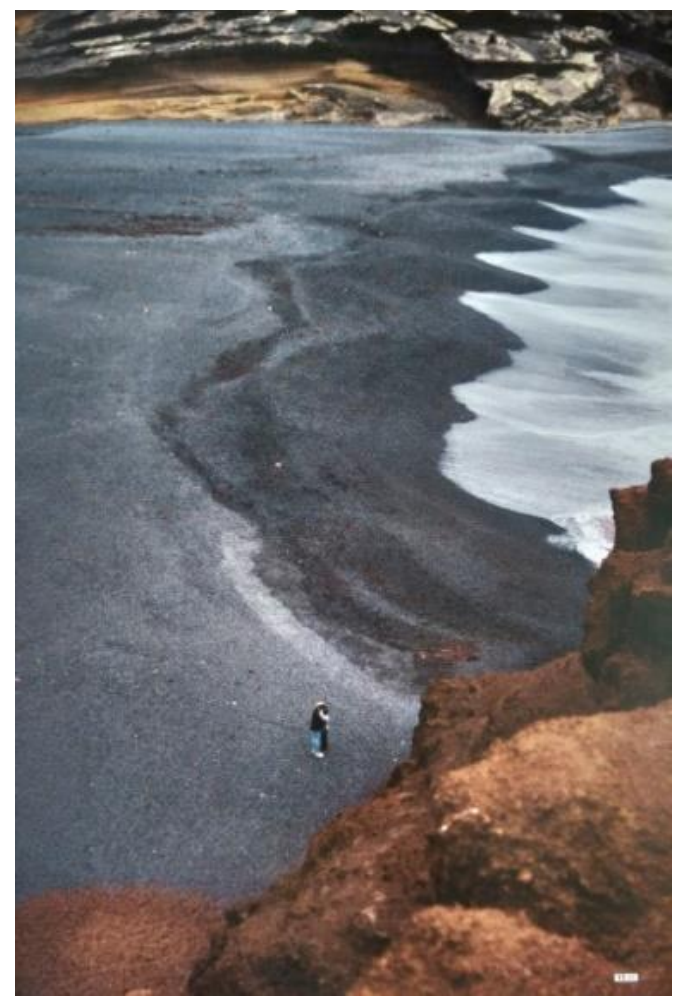

Figura 1: Fotografia da praia El Golfo, tirada por Almodóvar, onde aparece o casal abraçado. ${ }^{26}$

Como afirma Salles, "trata-se de uma imagem sensível que contém uma excitação. O artista é profundamente afetado por essa imagem que tem poder criativo; é uma imagem geradora. Essas imagens \{...\} podem agir como elementos que propiciam futuras obras" ${ }^{27}$. A imagem geradora é uma ocorrência bastante comum nos processos de criação de artistas. Essas imagens estão ligadas a uma certa vagueza, a mecanismos intuitivos inerentes aos projetos criativos.

Como reflete Steven Johnson, a maioria das intuições que se transformam em intuições inovadoras importantes se desenvolvem em intervalos de tempo bastante longos. E começam como uma sensação vaga de que existe uma solução para o problema. Essas intuições podem permanecer por décadas nas sombras da mente, criando novas conexões e ganhando forças para que um dia se transformem em algo mais substancial. E isso acontece, geralmente, por terem sido despertadas por um novo acúmulo de informações, ou pelo contato com outra intuição que sobrevive em outra mente, ou por uma associação interna que finalmente desenvolve o pensamento. Como essas intuições são lentas, elas são também criaturas frágeis e podem se perder com facilidade em meio aos afazeres do dia a dia. Então, o segredo de cultivar intuições é anotar tudo. Pois uma intuição que não se conecta a outra está fadada a continuar sendo meramente intuição, pois como ele afirma, "manter uma intuição lenta é menos uma questão de transpiração que de cultivo. Há que lhe dar alimento suficiente para mantê-la crescendo e plantá-la em solo fértil, onde suas raízes possam fazer novas conexões. Depois, basta lhe dar tempo para florescer". ${ }^{28}$

A escrita faz parte do desenvolvimento e da prática criativa do diretor em um processo que ele guarda, cultiva e desenvolve ideias. No caso aqui relatado anteriormente, sobre o processo de criação do filme "Abraços

\footnotetext{
${ }^{26}$ DunCAN, P.; PeIRó, B. Op. Cit., 2017, p. 356

${ }^{27}$ SALlES, C. Almeida. Op. Cit., 2013, p. 60

${ }^{28}$ Johnson, S. De onde vêm as boas ideias. Rio de Janeiro: Zahar, 2011, p. 68
} 
Partidos", Almodóvar agarrou a intuição de que aquela imagem possuía uma estória a ser revelada e saiu em busca dessa descoberta. Sua mente precisou passar por um processo de maturação, inclusive, abandonando a ideia em alguns momentos, dedicando-se a criar outros filmes, até que ele conseguisse encontrar a narrativa por inteiro.

No processo de elaboração da história que deseja contar, Almodóvar assume uma postura investigativa durante a criação de seus filmes. Por exemplo, na construção do roteiro de "A Flor do Meu Segredo", filme de 1995, em que faz perguntas e inventa dados que se tornam pistas que ele precisa seguir:

Curiosamente, em todos os meus filmes, a ideia de partida é uma cena que acaba ficando no meio do filme. Por exemplo, a sequência-mãe de $A$ flor do meu segredo é a cena em que a personagem de Marisa reencontra o marido e se zanga com ele. Foi a primeira coisa que escrevi, e depois me perguntei como aquela mulher chegou ali e como vai sair da enrascada. Procuro os locais em que a personagem viveu, as personagens secundárias que se relacionam com ela. É como o trabalho de detetive: sigo as pistas que eu próprio invento. ${ }^{29}$

O diretor também alimenta o seu processo de criação ficcional, colhendo fait-divers dos jornais, pois acredita que tudo que lê, ou que lhe dizem, ou todos os elementos da realidade que o circundam podem despertar o seu interesse e dar maior sentido ao material ficcional que ele já possui, ${ }^{30}$ ou seja, o artista cria conexões entre o mundo que o circunda e a obra que está em fase de criação.

Almodóvar também compra objetos e os coloca dentro de caixas na expectativa de que um dia encontre uma história, um filme. Mas o cineasta pondera: "perigo é que no fim esses objetos não sirvam para nada e se tornem objetos mortos. Isso acontece. Tudo o que escrevi não se tornará automaticamente um filme. Há coisas que estão ultrapassadas, mas outras são vibrantes." ${ }^{31}$ Esses objetos funcionam como "estímulos de escritório", como definiu o poeta Paulo Leminski ${ }^{32}$, geralmente trazidos pelo artista para o espaço de criação como elementos com potencial para deflagrar sensações e ideias, que podem ser fotografias, objetos ou mesmo qualquer outro elemento que desperte o interesse do artista. Pois um artista encontra diferentes meios de armazenamento de informações, que podem funcionar como auxiliares no percurso de criação, nutrindo o artista e a obra. São as provisões que o artista "recolhe, junta e acumula", que podem ser "registros verbais, visuais ou sonoros de apropriação do mundo" ${ }^{33}$, são seus arquivos.

Fica claro, com isso, a complexidade do percurso criativo, desmistificando a perspectiva de que o artista tem como ponto de partida um insight inicial, percorrendo um trajeto do caos até chegar à ordem, que seria a obra. O seu tempo de desenvolvimento é não linear, sendo constituído por um movimento onde reside um emaranhado de ações, que se dão em rede. Almodóvar admite que cultiva e persegue as histórias ao longo do tempo e afirma: "meu único método é seguir as histórias que me acompanham no decorrer do tempo, para um dia fazer delas um filme. ${ }^{34}$ Lembrando que nem tudo que ele escreve se tornará um filme, ou seja, existe um material que jamais chegará ao público, mas que foram imprescindíveis para o amadurecimento da linguagem ou mesmo das técnicas de trabalho do artista. Estas obras abortadas se transformam em arquivos e não possuem nenhuma outra finalidade, como pondera Salles:

\footnotetext{
${ }^{29}$ STRAUSS, F. Op. Cit., 2008, p. 243

${ }^{30}$ Ibidem, p. 263

${ }^{31}$ Ibidem

${ }^{32}$ SALLES, C. Almeida. Op. Cit., 2013, p. 63

${ }^{33}$ Ibidem, p. 128

${ }^{34}$ STRAUSS, F. Op. Cit., 2008, p. 264
} 
Ao observar diferentes processos de criação encontramos também inúmeras obras abortadas. São projetos que não se realizaram, mas que, nesses casos, tentativas foram feitas. Obras que foram desenvolvidas em algumas ou várias direções, mas nenhuma das escolhas feitas recebeu o aval do autor para entregá-las ao público. Muitas possíveis obras ficam guardadas nesse labirinto sem saída. ${ }^{35}$

Para a construção da obra, Almodóvar confessa que somente inicia o processo de escrita do roteiro quando possui muitas notas, dando bastante importância à coleta de informações e ao registro de ideias, como se fosse um processo de preparo e amadurecimento do universo ficcional que ele está criando ${ }^{36}$. Esse material funciona como estímulo. Assim, a coleta de dados e informações alimentam o processo criativo e direcionam a própria criação.

É importante observar que cada artista encontra os seus métodos de registros de ideias, não existindo um modelo a seguir. Almodóvar faz uso da palavra, pois é através da palavra que ele chega à imagem, tão essencial à arte cinematográfica. No entanto, as especificidades de cada processo de criação geram diferentes modos de raciocínio, fazendo com que cada artista encontre o seu método de trabalho. Podemos deduzir com isso, que um mesmo artista possa experimentar ou possa se colocar em situações nunca antes vividas, a partir da escolha de novos procedimentos de pesquisa e criação. $O$ importante é a tensão existente entre "o que se quer dizer e aquilo que se está dizendo, ${ }^{37}$ que caracteriza qualquer ato criador. Neste processo, existe um embate entre o desejo de concretização do artista e os limites que a realidade impõe. Almodóvar revela que o filme "Kika", lançado em 1993, rendeu as piores críticas, mas não foi devido a isso que o filme gerou a sua insatisfação:

Ao filmá-lo fui rapidamente obrigado a admitir que não poderia tirar nada dos dois intérpretes masculinos, Peter Coyote e Alex Casanova, que na realidade não foram feitos para os personagens que deveriam interpretar. O papel de Alex Casanova era muito mais interessante no roteiro, era um rapaz muito simpático e ao mesmo tempo repugnante. Faltava completamente a Alex Casanova a sensibilidade para fazer esse papel. Também tive desilusões com a técnica. Pedira coisas novas ao diretor de fotografia, porque Kika era um filme em que se podia jogar com o vídeo através da personagem da Victoria. Todos os ensaios que me mostraram com o vídeo não prestavam; eu queria controlar essa imagem de vídeo de forma que pudesse trabalhar a luz, mas não foi possível, e fui obrigado a renunciar a muitas ideias de direção, perdendo muito tempo. Visualmente, o filme foi uma grande frustração para mim. ${ }^{38}$

Portanto, a obra surge na tensão entre limite e liberdade, "liberdade significando possibilidade infinita e limite estando associado a enfrentamento de restrições." ${ }^{39}$ A liberdade permite que o artista faça escolhas, no entanto e, principalmente, faz com que ele seja responsável pela qualidade dessas escolhas, tanto aquelas escolhas que ele pode fazer, como aquelas que ele não pode, como no caso técnico que Almodóvar enfrentou, em relação ao seu desejo de manipulação da linguagem do vídeo dentro do filme, que o fez perder bastante tempo durante a filmagem em procedimentos sem bons resultados. Ele também chegou ao entendimento que os atores escolhidos, para interpretarem dois personagens importantes, não podiam oferecer o registro de interpretação

\footnotetext{
${ }^{35}$ SAlles, C. Almeida. Op. Cit., 2013, p. 152

${ }^{36}$ STRAUSS, F. Op. Cit., 2008, p. 243

${ }^{37}$ SAlles, C. Almeida. Op. Cit., 2013, p. 68

${ }^{38}$ STRAUSS, F. Op. Cit., 2008, p. 238

${ }^{39}$ SALles, C. Almeida. Op. Cit., 2013, p. 68
} 
que ele, como diretor, procurava como resultado do processo de criação desses personagens, revelando os limites que surgem durante a criação.

Limites internos ou externos à obra oferecem resistência à liberdade do artista. No entanto, essas limitações revelam-se, muitas vezes, como propulsoras da criação. O artista é incitado a vencer os limites estabelecidos por ele mesmo ou por fatores externos, como data de entrega, orçamento ou delimitação de espaço. ${ }^{40}$

Entretanto, existe uma dicotomia na relação do artista com o limite pois, ao mesmo tempo que o limite pode servir como elemento dinamizador do processo criativo, obrigando o artista a experimentar novas técnicas e procedimentos de trabalho, fazendo com que ele lide com aquilo que não foi previsto e buscando respostas para as questões que se colocam durante a criação, o limite pode também conduzir o artista a resultados insatisfatórios, explicitando a complexidade da relação entre o projeto poético e as possibilidades de execução deste projeto, portanto, o projeto acaba sendo o resultado dos procedimentos e encontros possíveis. Pois "criar livremente não significa poder fazer qualquer coisa, a qualquer momento, em quaisquer circunstâncias e de qualquer maneira. As delimitações são como as margens de um rio pelo qual o indivíduo se aventura no desconhecido." ${ }^{41}$

O limite pode ser também criado pelo próprio artista, estabelecendo as fronteiras do seu trabalho a fim de criar uma linguagem ou uma estética, como a definição de palheta de cores a serem utilizadas numa obra. Assim, os limites também podem servir à construção da obra, criando parâmetros e objetivos a serem alcançados, mas que foram conscientemente pensados pelo artista como proposta estética ou mesmo de linguagem.

O depoimento de Almodóvar, citado acima, também nos provoca a refletir sobre a questão da experimentação como mecanismo de criação. Ele fez uma série de testes, pretendia controlar a imagem do vídeo e, mesmo quando ele vai para a sala de ensaio com os atores, na verdade, está trazendo, como técnica de trabalho, a prática da experimentação. Ou seja, o processo de criação é marcado por sua natureza investigativa.

O cineasta construiu uma metodologia de trabalho que considera a experimentação como uma etapa, assim, essa experimentação acontece na sala de ensaio, onde constrói com os atores os personagens a partir da realidade de seus corpos, na forma como filma, fazendo muitos planos de acordo com a perspectiva de diferentes personagens, para então criar diversas alternativas dramatúrgicas de montagem e construir a narração final do filme, ou mesmo, quando se permite improvisar com os atores durante as filmagens. Ou seja, a improvisação e a experimentação fazem com que ele amplie as possibilidades de descobertas do formato do filme final:

A montagem me interessa muito e tive oportunidade de editar todos os meus filmes com o mesmo montador, José Salcedo, que é excelente. O trabalho dele se desenvolve sobretudo no momento daquilo que aqui chamamos el afinado - isto é, os últimos detalhes, as últimas correções da montagem -, trabalho que, nesse momento, se torna muito sutil. Nessa hora é preciso saber encontrar os dois fotogramas que se deve suprimir numa cena para intervir no ritmo da narração. Mas a montagem de meus filmes impõe-se em primeiro lugar pela planificação do trabalho, sendo até ditada pela forma como filmo. Agora que tenho mais dinheiro e que sinto mais o medo da filmagem, faço muito mais tomadas que antes. Normalmente, filmo várias versões de uma mesma sequência, diferente, sobretudo, do ponto de vista do tom - a escala de planos não varia, ou varia muito pouco -, e tento filmar cada cena de acordo com a visão de cada personagem que nela participa. Faço isso principalmente para ter mais possibilidades no momento da montagem. A narração, a estrutura do filme já devem

\footnotetext{
${ }^{40}$ Ibidem, p. 69

${ }^{41}$ Ibidem
} 
ter sido impostas pelo argumento, mas pode-se dizer que o local onde se desenvolve a narração do filme é a mesa de montagem. Fazer muitas tomadas é particularmente interessante para o trabalho com os atores. ${ }^{42}$

Fica evidente que outras possibilidades dramatúrgicas, que foram descartadas, desencadeariam outros formatos finais. Assim, temos a questão das escolhas, feitas a partir do olhar de um artista, determinando os direcionamentos do processo criativo, mas que é marcado por um sentimento de incerteza, ou seja, "preferimos falar da experimentação como movimento e não como evolução; não há segurança por parte do criador, de que a obra em construção esteja caminhando de uma forma pior para outra melhor." ${ }^{\text {"3 }}$ Dessa maneira, a experimentação é um processo marcado por idas e vindas, por descobertas e retomadas, por aceitação e negação, sem nenhuma garantia de obtenção de plena satisfação. Como metodologia de trabalho, é um procedimento arriscado, mas fundamental, porque é a partir da experimentação que o artista pode ir ajustando os elementos que constituem a obra, até que encontre o formato ou o registro que lhe interessa e que esteja de acordo com o seu projeto poético.

Estamos no universo da concretização do projeto poético do artista, em que a experimentação mostra-se como seu momento de exploração. Ao corrigir ou modificar uma possível concretização de seu grande projeto, o artista vai explicitando para ele próprio o que espera da obra e, assim, seus propósitos ganham contornos mais nítidos. Ao mesmo tempo, esse mesmo conjunto de princípios coloca a obra em constante avaliação e julgamento. ${ }^{44}$

Somado a isso, o domínio das formas de manipulação da matéria prima, escolhida pelo artista para trabalhar, faz com que ele possa extrair as qualidades dessa matéria, em favor da criação da obra. Um roteirista tem como matéria prima o enredo, os personagens, os ambientes da história, os quais ele pode criar relações e construir trajetórias surpreendentes a partir do domínio das técnicas de criação do roteiro, pois pode trabalhar com elipses, com fragmentação, com estruturas invertidas, com o tempo dramático, brincar com o ritmo da narrativa, criar momentos de suspensão, de mistério, de tensão, fazendo uso da manipulação de informações que só ele conhece. Um diretor de cinema tem como matéria prima os atores, a direção de arte, os enquadramentos fotográficos de cada cena, o clima ficcional, as cores, a construção das imagens, os sons, a música, enfim, uma série de elementos que são utilizados e combinados para criar o resultado que o cineasta anseia.

Sendo assim, a escolha da natureza da matéria prima pode determinar o resultado final. Quando Almodóvar opta por convidar um ator para interpretar uma personagem, ele terá que trabalhar a partir dos registros de interpretação que aquele ator consegue alcançar. Ao dirigir o ator Gael Garcia Bernal, no filme "Má Educação", lançado em 2004, Almodóvar descobriu que o ator trazia com mais facilidade uma faceta da personagem, então passa a explorar esse elemento. Lembrando que o diretor geralmente adapta suas personagens aos atores que irão interpretá-las:

Quanto a Gael, talvez também por razões culturais, uma vez que ele vem do México, não inspira e não provoca esse sentimento lúdico e terno que poderia ser conveniente à personagem de Juan. Quando filmamos as cenas em que ele interpreta Juan, em contrapartida, ele exprimia muito bem sua dureza implacável e mesquinha. Tentei fazer com que a personagem tivesse um pouco mais de humor e calor, mas não pegou. Por isso adaptei a

\footnotetext{
${ }^{42}$ STRAUSS, F. Op. Cit., 2008, p. 137

${ }^{43}$ SAlles, C. Almeida. Op. Cit., 2013, p. 153

${ }^{44}$ Ibidem, p. 154
} 
personagem de Juan àquilo que Gael inspira, o que não quer dizer que tenha renunciado a uma parte da personagem, mas sim que tirei o máximo partido daquilo que Gael me oferecia inconscientemente: uma parte mais sombria, muito interessante para o filme. ${ }^{45}$

Portanto, o que poderia ser considerado uma limitação passa a direcionar novas descobertas. Gael Garcia Bernal trazia com muita facilidade o aspecto sombrio da personagem e sentia dificuldade em trazer o registro lúdico, então, Almodóvar explorou esse elemento, utilizando-o na construção da personagem, pois acreditou que era uma característica que dialogava com o universo fílmico em criação. Logo, ele manipula a sua matéria prima, o ator, em favor da construção da dramaturgia do roteiro, já que explora, em maior profundidade, um determinado caráter da personagem. Como afirma Fayga Ostrower:

Dentro de nossas possibilidades procuramos alcançar a forma mais ampla e mais precisa, a mais expressiva. Ao transformarmos as matérias, agimos, fazemos. São experiências existenciais - processos de criação - que nos envolvem na globalidade, em nosso ser sensível, no ser pensante, no ser atuante. Formar é mesmo fazer. É experimentar. É lidar alguma materialidade, e, ao experimentá-la, é configurá-la. Sejam os meios sensóriais, abstratos ou teóricos, sempre é preciso fazer ${ }^{46}$.

Assim, as qualidades da matéria prima são, ao mesmo tempo, limitadoras e provocadoras de novas possibilidades, podendo modificar a expressão artística, pois fazem com que o artista se coloque em movimento, em busca de formas de trabalhar a matéria-prima com as qualidades intrínsecas a ela, que se revelam durante o processo da criação.

No trabalho, o homem intui. Age, transforma, configura, intuindo. O caminho em toda tarefa será novo e necessariamente diferente. Ao criar, ao receber sugestões da matéria que está sendo ordenada e se altera sob suas mãos, nesse processo configurador o indivíduo se vê diante de encruzilhadas. A todo instante, ele terá que se perguntar: sim ou não, falta algo, sigo, paro... Isso ele deduz, e pesa-lhe a validez, eventualmente a partir de noções intelectuais, conhecimentos que já incorporou, contextos familiares à sua mente. Mas, sobretudo, ele decidirá baseando-se numa empatia com a matéria em vias de articulação. Procurando conhecer a especificidade do material, procurará também, nas configurações possíveis, alguma que ele sinta como mais significativa em determinado estado de coordenação, de acordo com seu próprio senso de ordenação interior e o próprio equilíbrio. ${ }^{47}$

Como vimos, a manipulação da matéria-prima pode fazer com que ela ganhe artisticidade. Um exemplo é a manipulação que Almodóvar faz de alguns elementos da cultura popular, como os enredos melodramáticos, ou mesmo o caráter barroco de suas imagens e personagens, carregadas de cores e informações. Ao ir selecionando e criando relações entre elementos, muitas vezes, pouco valorizados pelos patrocinadores do dito "bom gosto" estético, Almodóvar faz com que algo considerado feio ou de mau gosto ganhe valor artístico pela forma com que manipula esse elemento, criando tessituras visuais carregadas de singularidade, ou seja, "isto

\footnotetext{
${ }^{45}$ STRAUSS, F. Op. Cit., 2008, p; 269

${ }^{46}$ Ostrower, Fayga. Criatividade e processos de criação. Petrópolis: Vozes, 2014, p. 79

${ }^{47}$ Ibidem, p. 70
} 
nos leva a afirmar que a expressividade artística não é intrínseca a esta ou aquela matéria-prima. Sob esta perspectiva, todas tem potencialidade, tudo depende do uso que será feito dela." ${ }^{48}$

É importante observar que Almodóvar é o roteirista e o diretor de seus filmes. Sendo assim, ele pode modificar, com muito mais liberdade, aspectos do roteiro. $\mathrm{O}$ fato do cineasta acumular as duas funções promove o intercâmbio dessas funções, ou seja, ele passa a trabalhar, em determinado momento, tanto na revisão da dramaturgia do roteiro, como na construção da materialidade fílmica, o que permite que ele possa transformar personagens, cortar diálogos ou aumentá-los conforme o seus processos de aprofundamento, pode tirar e acrescentar cenas, manipular a estrutura dramática para que alcance um determinado resultado. Em vista disso, a construção do discurso do filme, através da manipulação de situações e imagens, ocorre na intersecção entre o olhar do roteirista e o olhar do diretor.

Almodóvar gosta da artificialidade, pois o que o seduz como diretor é o artifício e a representação. ${ }^{49}$ Como ele mesmo afirma, "uma das coisas mais maravilhosas que o cinema proporciona: fazer do inverossímil, algo verossímil. ${ }^{50} \mathrm{E}$ uma de suas técnicas como diretor é tratar seus argumentos de forma naturalista e com veracidade. Para conseguir essa qualidade, ele afirma utilizar como recursos os diálogos e a interpretação dos atores, os quais são dirigidos a agirem com naturalidade diante de qualquer situação, mesmo que seja uma situação delirante e escabrosa.

Para trabalhar essa artificialidade, o diretor utiliza, como procedimento de criação, a subversão ou a hiperbolização do real. Ou seja, a partir do cotidiano, ele imagina e cria novas situações, subvertendo os elementos que as tornam fora do senso comum, possibilitando fugir dos clichês. Ele afirma sobre estes aspectos:

Quando falo da realidade penso em algo que existe, que se pode apreender para mostrar, mas também para deformar. É uma representação. A realidade me interessa como objeto representável e como elemento para construir uma ficção. É verdade que as emoções assim provocadas estão ligadas a essa realidade indiscutível que é a da nossa própria existência, da nossa própria sensibilidade, mas para mim um filme será sempre uma representação, e uma representação comporta sempre um artifício. Falar da realidade é falar também de manipulação. ${ }^{51}$

Assim, em toda a sua filmografia, encontramos exemplos de como ele manipula a realidade e a subverte. Tomo como exemplo o filme Pepi, Luci, Bom y otras chicas del mónton, lançado em 1980, há um concurso de "Ereções Gerais" numa festa, onde os convidados escolhem, entre os candidatos, colocados em pé num pequeno palco improvisado, a melhor ereção. A cena é apresentada pelo próprio Almodóvar, que surge como um anfitrião da festa. O dono da melhor ereção será coroado "Rei da Noite" e poderá escolher fazer o que quiser, com quem quiser, sugerindo um encontro sexual pelo próprio anfitrião. $\mathrm{O}$ vencedor acaba escolhendo a personagem "Luci", aparentemente a mais recatada entre as três amigas, já que é uma dona de casa, para lhe fazer sexo oral, o que é feito publicamente, diante de todos os convidados, que agem como se fosse algo absolutamente natural. Nesta situação, ele deforma os concursos de beleza, tão comuns na cultura ocidental e, ao mesmo tempo, faz referência, de maneira irônica, a um momento político importante após a ditadura franquista, as "Eleições Gerais”, convocadas em 1977, na retomada do processo democrático espanhol. Uma paródia ácida dos concursos

\footnotetext{
${ }^{48}$ SALLES, C. Almeida. Op. Cit., 2013, p. 77

${ }^{49}$ STRAUSS, F. Op. Cit., 2008, p. 145

${ }^{50}$ Ibidem, p. 43

${ }^{51}$ Ibidem, p. 184
} 
de beleza e talvez um comentário sobre as eleições convocadas, que pode ser interpretado como um momento de gozo, de prazer para o povo espanhol.

$\mathrm{Na}$ criação ficcional é muito importante que o autor consiga criar um mundo consistente, com regras internas de causa e consequência, mesmo que o universo ficcional seja absolutamente absurdo, pois "cada realidade ficcional estabelece de forma única como os eventos acontecem em seu interior." ${ }^{52}$ Almodóvar, frequentemente, apresenta em seus filmes situações que extrapolam o sentido de realidade. Este tipo de artifício do diretor está ligado ao seu modo de fazer cinema, como ele próprio afirma:

Faço filmes que encontram sua origem na realidade, mas que não são estudos de costumes realistas. A realidade me dá a primeira linha do argumento, mas a segunda sou eu que invento. Essa segunda linha não aperfeiçoa a realidade a não ser do ponto de vista dramático, não a torna melhor ou mais bonita, torna-a mais interessante cinematograficamente. Por exemplo, em "De Salto Alto", a primeira linha do argumento me é dada pela realidade: uma apresentadora de noticiário televisivo anuncia o assassinato de um homem. E em seguida inventa-se a segunda linha: a apresentadora confessa ao vivo ser a assassina. Da primeira à segunda, trata-se simplesmente de maior intensidade dramática. ${ }^{53}$

Assim, o cineasta, ao inventar situações tendo como base a realidade, constrói uma outra realidade consistente para as suas estórias, utilizando como técnica criativa a hiperbolização da realidade. O mundo que ele nos apresenta assemelha-se ao real, mas não pretende espelhar o real. A situação do concurso de melhor ereção numa festa, tratado sem nenhum estranhamento, em um ambiente cotidiano, extrapola o sentido de realidade, mas em nenhum momento desacreditamos da realidade ficcional construída por Almodóvar, já que ele trabalha com a criação de realidades consistentes, que "são ambientes ficcionais que estabelecem modos de interação entre os personagens e seu mundo, mantidos consistentemente ao longo da narrativa para explicitar seu significado" ${ }^{54}$. Lembrando que a finalidade maior de uma história é revelar diferentes aspectos da condição humana, pois "estórias são metáforas para a vida. Elas nos levam do factual ao essencial".

Existe em cada artista um universo perceptivo que determina a singularidade do seu olhar. Almodóvar, para criar seus universos fílmicos, comumente, seleciona os personagens marginais e pertencentes às minorias sociais, assim como elementos das tradições folclóricas espanholas, da publicidade, do cinema, da literatura, do teatro, das histórias em quadrinho, do melodrama, da comédia, etc. Todos esses universos são articulados por ele, utilizando para isso a sua percepção de mundo, numa relação sensorial direta com tudo que o cerca, colocando a questão do afeto e do que agrada ao seu olhar como algo importante. Assim, Almodóvar experiencia o seu trabalho, articulando o sensível e o intelectual, mas, principalmente, permitindo-se mergulhar livremente nas coisas do mundo.

\section{Referências bibliográficas}

DunCAN, Paul, en colaboración con PeIRó, Bárbara. Los Archivos de Pedro Almodóvar. Köln: Taschen, 2017.

FERreIRA, Glória; COTRIM, Cecilia. Escritos de artistas: anos 60/70/seleção e comentários. Rio de Janeiro: Jorge Zahar Ed., 2006.

\footnotetext{
${ }^{52}$ MCKEE, R. Story: substância, estrutura, estilo e os princípios da escrita de roteiro. Curitiba: Arte \& Letra, 2006, p. 63

${ }^{53}$ STRAUSS, F. Op. Cit., 2008, p. 239

${ }^{54}$ MCKEE, R. Op. Cit., 2006, p. 63

${ }^{55}$ Ibidem, p. 62
} 
JoHnSON, S. De onde vêm as boas ideias. Rio de Janeiro: Zahar, 2011.

MCKEE, Robert. Story - Substância, estrutura, estilo e os princípios da escrita de roteiro. Curitiba: Arte e Letra, 2010. Ostrower, Fayga. Criatividade e processos de criação. Petrópolis: Vozes, 2014.

SALLES, Cecilia de Almeida. Gesto inacabado: processo de criação artística. São Paulo: FAPESP: Editora Annablume, 2011.

SALLES, Cecilia de Almeida. Processos de criação em grupo. São Paulo: Estação das Letras e Cores, 2017

SALLES, Cecilia de Almeida. Redes da criação construção da obra de arte. São Paulo: Editora Horizonte, 2006.

STRAUSS, Frederic. Conversas com Almodóvar. Rio de Janeiro: Zahar, 2008. 